\title{
MONETARY ALLOWANCE FOR LAW ENFORCEMENT OFFICIALS TEMPORARILY SERVING ABROAD: FOREIGN EXPERIENCE
}

\author{
Dmytro Andreiev ${ }^{1}$ \\ National Academy of Internal Affairs, Ukraine \\ Ruslan Bilokin² \\ Higher Educational Institution of Ukoopspilka "Poltava University of Economics and Trade", Ukraine \\ Elena Tikhonova ${ }^{3}$ \\ National Academy of Internal Affairs, Ukraine
}

\begin{abstract}
The aim of the article is to analyse foreign experience in regulating the monetary allowance for law enforcement officers temporarily serving abroad, distinguish features of setting the rates and types of the monetary allowance for this category of workers in some foreign countries, and ascertain the order of the monetary allowance for police officers, who are temporarily serving outside Ukraine. The subject of the study is the foreign experience of the monetary allowance for law enforcement officers temporarily serving abroad. Methodology. The research is based on a comparison of the monetary allowance of law enforcement officers temporarily serving abroad in Ukraine and in foreign countries. Based on the analysis of the monetary allowance features for this category of law enforcement officers in Germany, France, Spain, the United States, Turkey, and in some other countries, the advantages and disadvantages of different conditions and procedure for the monetary allowance are determined. On the basis of a comparative legal study of certain provisions of Ukrainian legislation, the possibilities and limits of applying positive foreign experience in this area are determined. The results of the study revealed that the international experience of the labour remuneration of law enforcement officers temporarily serving abroad, as a rule, provides for the monetary allowance for employees based on the features of state regulation in this sphere and varies according to the source of funding and the principles for determining the rate of salary and compensatory payments, payments for moving to a new place of service and the quality of life of the state of a temporary service. Practical implications. The positive experience of the monetary allowance for law enforcement officers temporarily serving abroad proves that in order to increase the interest of law enforcement officials, including police officers temporarily serving outside Ukraine, higher legal and social protection of these persons and their family members should be ensured, including gradual approximation of the level of the monetary remuneration for the performance of official duties to the level of similar payments in the states of Central Europe. Relevance/originality. Conducting a comparative analysis of the monetary allowance for law enforcement officials temporarily serving abroad is the basis for developing the most promising directions for the development of domestic legislation in this area.
\end{abstract}

Key words: law enforcement bodies, police, monetary allowance, service abroad.

JEL Classification: K19, E42, E52

\section{Introduction}

Over recent decades, there is a tendency in the world to intensify the interaction of police units of foreign countries at the international level. This issue was raised initially at the First International Congress of Judicial
Police, which took place at the initiative of Prince Albert I in Monaco in 1914. Already then, the head of the Congress, Professor A. Larnie (France), said that direct contact between the courts and police of different countries became increasingly necessary every year. Any

\footnotetext{
Corresponding author:

${ }^{1}$ Educational and Research Institute №1, National Academy of Internal Affairs.

E-mail:dmitro@gmail.com

${ }^{2}$ Department of Law, Higher Educational Institution of Ukoopspilka "Poltava University of Economics and Trade".

E-mail: Ruslan1974@gmail.com

${ }^{3}$ Department of Financial Security and Financial Investigation, Educational and Research Institute No. 1, National Academy of Internal Affairs.

E-mail: gavruha@ua.fm
} 
delays in prosecuting and arresting criminals abroad must be eliminated (Gordienko, 2007).

Nowadays, international police cooperation is carried out by international organizations, on a regional scale and between the police of several countries. It has an objective basis, close relationship, and sometimes the interdependence of states in the modern world, which, consequently, leads to the internationalization of crime. Growth and qualitative changes in crime cause the interest of various national police systems to seek cooperatively the most effective ways, means, and methods to counteract criminal manifestations (Gubanov, 2000).

Such an interaction is carried out in several key directions, which include: providing legal assistance in criminal cases; conclusion and implementation of agreements on combating transnational crime; execution of decisions of foreign law enforcement bodies in criminal cases; regulation of legal issues and human rights in enforcing law and order; exchange of information of mutual interest to law enforcement bodies; joint investigation of counteraction to crime issues; exchange of experience in law enforcement work; assistance in training of personnel for foreign law enforcement agencies; provision of logistical and consultative assistance; organization of representative offices of law enforcement bodies in foreign states.

International police cooperation develops within these directions. It can be defined as combined efforts of the police of different countries to increase the effectiveness of the strategy and tactics assigned to its competence in the prevention, termination and investigation of offenses, as well as measures for the management of police forces, personnel, scientific and methodological and technical support for their work.

Therefore, the study of foreign experience in the monetary allowance for law enforcement officers temporarily serving abroad is becoming relevant and important since the financial support of the personnel, who performs such tasks, is not the last factor affecting the quality of law enforcement performance abroad, which determines the relevance of the chosen topic.

A significant contribution to the study of the monetary allowance for law-enforcement bodies temporarily serving abroad was made by foreign and domestic scientists such as G. Vedel, V. V. Hordienko, A. V. Hubanov, V. H. Hritsenko, R. Drago, V.O. Zarosylo, J. Insiardy, K. Kenny, K. Marfy, M. V. Plugatyr, A. I. Subbot, Yu. I. Rymarenko, V. L. Filsthein, O. R. Shevchuk, and others.

The aim of the article is to analyse the foreign experience of regulating the monetary allowance for law-enforcement bodies temporarily serving abroad, single out the features of setting the rates and types of the monetary allowance for this category of workers in some foreign countries, and clarify the procedure for the monetary allowance for police officers temporarily serving outside Ukraine.
The main material. At the UN General Assembly in September 1991, it was noted that the increase in crime, combined with its acquisition of a transnational character, endangered the internal security of states, impinged on the freedom of a person to live without fear, and might undermine international relations. All of this requires the creation of effective international mechanisms and closer cooperation between states. As a rule, international police cooperation is carried out in the following forms: exchange of information about persons (suspects in the commission of crimes, wanted, their relations, addresses, etc.), the facts of crimes; verification of suspects' testimonies; identification of persons or stolen objects by photo or description; conducting interrogations or polls of citizens; obtaining data from foreign organizations, institutions, trade and industrial enterprises; forwarding documents. Some interagency agreements provide for the possibility of the presence of police officers of one state in another state in carrying out operational and investigative actions that are of interest to them, attracting foreign experts for conducting expert assessments and various types of strategic and tactical consultations.

In order to ensure the efficiency of the departmental mutual assistance provision, some states include in their diplomatic and other representations abroad both individual police officers and entire units.

For example, the FBI has its own official representatives in more than 30 countries, the Office of National Drug Control Policy in more than 40, and the Secret Service in almost 50 countries.

In the UK, Germany, France, this form of cooperation with foreign police bodies is widely used. Established in the United Kingdom in April 1992, the National Criminal Intelligence Service had a branch office in 15 countries in a year, while personnel of the Federal Office of Criminal Police of Germany worked in 1996 at 25 embassies in West Germany. In the same year, French police had units in 20 states, the United States, Canada, Columbia, the Netherlands, Pakistan, Thailand and others (Gubanov, 2000).

In addition, the activities of police officers of any state abroad should be clearly regulated by the legal acts of the host country. Otherwise, an imminent threat or a real violation of the principle of state sovereignty occurs.

In general, the activities of the above-mentioned foreign police missions are carried out between most countries on the basis of relevant international treaties.

In the world practice, there are the following forms of temporary service abroad by law enforcement officers:

- service at the embassy of the state, as a police representative;

- protection of diplomatic missions;

- service in the UN peacekeeping contingent;

- service within the framework of the interstate agreements on the assistance of the foreign police. 
A police officer, who serves at the Embassy of the state embassy as a police representative of his state, acts as a liaison officer, "a police attaché." Each state sets legislative requirements for candidates for a position of a police representative abroad.

The tasks of police attachés mainly include collecting, analysing, and transmitting the necessary information, preparing proposals for conducting joint operations and further coordinating with the law enforcement bodies of the host country, etc. (Zimin, Zubov, 1993).

For example, in France, the international representation of law enforcement bodies is carried out in three directions:

- The International Police Technical Cooperation Service (SCTIP) of the French Ministry of Interior;

- Attaché on Internal Security (ASI);

- Agencies for External Borders EC FRONTEX (Fronteks - Yevropeiskoie agentstvo po upravleniiu operativnym sotrudnichestvom na vneshnikh granitsakh gosudarstv-chlenov Yevropeiskogo Soiuza).

For the support of French police officers abroad, the budget provides 1.98 billion euros, which is $8 \%$ of the total budget of the police ( 24.2 billion euros). At the same time, the amount spent on the material provision of police officers increases each year.

In the United States, for candidates for service in the police station abroad, there are several criteria: age (in most states, more than 20 years); education (education of a specialty in law-enforcement activity, criminology, and psychology) and health status (Yak staty politseyskym atashe chy ofitserom zviazku).

The remuneration of foreign police officers is mainly determined by funding from the Ministries of Foreign Affairs of the state or similar bodies dealing with international cooperation.

In the United States, the rate of the monetary allowance for a police representative abroad corresponds to the rate of his/her position in his home country. For example, the initial rate ranges from 25 to 33 thousand dollars per annum, while the average amount of the monetary allowance is 52 thousand dollars. The average salary of the FBI legal attaché is 38,271 dollars. The final rate of the salary of a police officer abroad depends largely on the country where the police officer is being sent (Yak staty politseyskym atashe chy ofitserom zviazku).

In Israel, the monetary allowance of a police attaché is paid by the budget of neither the police nor the Ministry of Internal Security, but the Ministry of Foreign Affairs. The foreign ministry has a strict division into ranks and, therefore, the police attaché cannot receive the same salary as a professional diplomat of a higher rank. Thus, according to Israeli law, a police attaché in Washington DC is provided for the salary of $\$ 27,800$ per month regardless of the salary he/she has received in the Israeli police station (General politsii predpochel Vashingtonu Iudeiu i Samariiu).
In Spain, the police have representatives in 68 countries. The salary of police attachés depends on the remoteness, quality of life, and risk to the life of a police officer, which is determined by the analysis of the political, social, and economic situation in the state where the embassy is located. These criteria are fixed as modules, set by the Ministry of Economy and Finance each year. Of the 68 diplomatic missions, a service in 51 (including Havana, Yemen, Islamabad, Algeria, Cairo, Mauritania, Istanbul, Buenos Aires, Morocco, Mexico, Lima, Caracas, etc.) is considered dangerous. For serving in the most dangerous country, the largest module is used, on which the basic salary for the police officers of Spain is multiplied.

For example, the average monetary allowance provided for a commissioner in Spain is 3664 euros per month, while the representative of the diplomatic mission of the Spanish Ministry of Internal Affairs in Iraq, with the module, is approximately 29,700 euros. The rate of the monetary allowance is lower for a representative in Angola, the Democratic Republic of the Congo, the Republic of Korea, Hong Kong, Ukraine, Japan, and Norway (Yak staty politseiskym atashe chy ofitserom zviazku).

Considering the service of police officers abroad, related to the protection of diplomatic missions, it should be noted that for these purposes employees are usually sent for 18 months. In the general procedure, as well as police attachés, mentioned persons receive the monetary allowance, which includes the salary and compensations related to travel expenses, the risk to life, etc.

Furthermore, the rate of the salary also depends on the position occupied by a police officer. For example, the Spanish police inspector in Iraq receives about 19,500 euros a month, in Switzerland - about 7,900 euros, in Turkey - 3,800 dollars.

In addition, the salary calculation procedure is maintained depending on the country of service. Contrasting service at embassies, the service within peacekeeping missions is funded by the United Nations, the monetary fund of which is formed by contributions from participating countries.

Ukraine also does not stand aside this trend of international police cooperation. The peacekeeping activity is quite diverse, and over the last two decades, the deployment of peacekeeping forces has taken place within various configurations. At present, 17 UN peacekeeping operations varying in size, composition and range of tasks are deployed on four continents, and in six of the operations, representatives of the Ministry of Internal Affairs of Ukraine attend.

Considering the prospects of developing cooperation with the UN, in 2011, the leadership of the Ministry of Internal Affairs of Ukraine took the principled decision to open a permanent representative office of Ukraine in the United Nations in New York as a representative of the Ministry of Internal Affairs of Ukraine, which 
provided an additional impetus to cooperation of the Ministry of Internal Affairs with the UN Secretariat (Mizhnarodna myrotvorcha diialnist MVS Ukrainy. Perspektyvy rozvytku na 2015 rik).

The financial support for peacekeeping personnel, a part of which is the Ukrainian police, plays an important role in the efficient implementation of peacekeeping activities.

The strategy of the international peacekeeping activity of Ukraine provides for that in order to increase the interest of members of the armed forces, senior and ordinary staff of the internal affairs bodies and civilians in participating in international peacekeeping operations, a higher legal and social protection of participants in international peacekeeping operations and members of their families should be ensured, including a gradual approximation of the level of monetary remuneration for the performance of official duties in peacekeeping contingents or peacekeeping personnel to the level of similar payments in the states of Central Europe (Pro rishennia Rady natsionalnoi bezpeky i oborony Ukrainy vid 24 kvitnia 2009 roku).

In accordance with the Law of Ukraine "On Participation in International Peacekeeping and Security Operations," financing of expenses related to Ukraine's participation in international peacekeeping operations can be:

- either funded by the state budget provided the full or partial reimbursement of these expenses funded by funds allocated by the United Nations, NATO, the EU, the OSCE or other international organization for the financing of an international peacekeeping operation or within concluded international agreements of Ukraine;

- either funded by the state budget;

- either funded by the funds allocated by the United Nations, the OSCE or another international organization to finance an international peace-keeping and security operation (Pro uchast Ukrainy $\mathrm{v}$ mizhnarodnykh operatsiiakh z pidtrymannia myru i bezpeky: Zakon Ukrainy vid 23.04.1999 r.).

According to the Resolution of the Cabinet of Ministers of Ukraine "On Approval of the Procedure for Material and Technical and Financial Support of the National Contingent and National Personnel of Ukraine participating in International Peacekeeping and Security Operations," for persons, who are the part of the national contingent and national personnel of Ukraine, during the performance of official duties outside Ukraine, payments in national currency are kept in the amount of 100 percent of the official salary or average wage payment for the last place of service or work, salary for the military (special) rank, allowances for seniority, and other monthly supplemental allowances of a permanent nature.

The expenses incurred in relocating of the national personnel of Ukraine of the OSCE mission to the location of the OSCE Secretariat and back to Ukraine are funded by expenditures approved by the central government executive bodies that send this personnel to the OSCE mission under the relevant budget programs (Pro zatverdzhennia Poriadku materialnotekhnichnoho i finansovoho zabezpechennia natsionalnoho kontynhentu ta natsionalnoho personalu Ukrainy, yakyi bere uchast u mizhnarodnykh operatsiiakh z pidtrymannia myru i bezpeky: Postanova Kabinetu Ministriv Ukrainy vid 11 lypnia 2002 r. № 963).

The Ministry of Internal Affairs of Ukraine determines directly the procedure for providing the monetary allowance and monthly monetary compensation in foreign currency for police officers serving as a part of peacekeeping personnel.

In particular, for social protection of the national personnel of the Ministry of Internal Affairs of Ukraine and members of their families during the stay in the international peacekeeping and security operation for the staff of the law enforcement bodies, the salary is maintained, and paid by the financial support and accounting department of the Ministry of Internal Affairs at the submission of financial units, where an employee has served before a referral to participate in peacekeeping and security operations. The amount of employee's monthly salary is credited to his bank account, which can then be obtained by authorized persons.

The monthly monetary payment in foreign currency for the national personnel of the Ministry of Internal Affairs of Ukraine, which is a part of the special units and canine peacekeeping units of the Ministry of Internal Affairs of Ukraine, is paid by the budget program, which ensures the activities of the Ministry of Internal Affairs of Ukraine for the maintenance of peace and security, if specified by the memorandum between Ukraine and the international organization that manages the mission.

To provide immediate needs of national personnel of the Ministry of Internal Affairs of Ukraine, who is a part of special and canine units, an advance of USD 250 per person (at the request of a recipient), which is held during the calculation of the monthly monetary remuneration in a foreign currency for the current month, is paid one time before departure from Ukraine (Pro zatverdzhennia Instruktsii shchodo orhanizatsii prokhodzhennia sluzhby pratsivnykamy orhaniv vnutrishnikh sprav, viiskovosluzhbovtsiamy vnutrishnikh viisk MVS Ukrainy, yaki napravleni dlia uchasti v mizhnarodnykh operatsiiakh z pidtrymannia myru i bezpeky: Nakaz MVS Ukrainy vid 07.12.2003 № 1490).

With regard to the rate of the monetary remuneration, they are set by the Cabinet of Ministers of Ukraine. In particular, nowadays, the rate of the monthly monetary remuneration in foreign currency for the performance of official duties outside Ukraine by a police officer, included in the national staff for participation in international peacekeeping and security operations, funded by the state budget, are in US dollars: 
- a unit commander - 1020;

- a deputy commander of the unit, a deputy commander of the unit and the chief of staff, a chief of staff - 1000;

- a company commander, a staff officer, a personnel officer, a technician and armament officer, an officer dealing with planning and combat and special training, dealing with mission-link relations, logistics and technical support - 980;

- a deputy commander of the company, a platoon commander, an interpreter on duty, an interpreter;

- a deputy commander of the platoon, a deputy commander of the platoon and an interpreter, a head of the department - 940;

- a deputy chief of the department, a commander of the department (group) - 920;

- a senior inspector, a senior engineer, a specialist, a doctor, a veterinarian, an accountant, a psychologist, a lawyer - 900;

- a driver, a driver of the armoured personnel carrier,

a technician driver, a cynologist, an instructor, an explosive engineer, an inspector, an engineer - 880;
- a patrol, a cook, a nurse, a paramedic, a veterinary nurse - 860 (Deiaki pytannia finansovoho zabezpechennia viiskovosluzhbovtsiv Natsionalnoi hvardii ta politseiskykh, vkliuchenykh do skladu natsionalnoho personalu dlia uchasti v mizhnarodnykh operatsiiakh $\mathrm{z}$ pidtrymannia myru i bezpeky: Postanova Kabinetu Ministriv Ukrainy vid 22 travnia 2013 r. № 358).

\section{Conclusion}

Therefore, the international experience of the remuneration of law enforcement officers, who temporarily serve outside the territory of the state, as a rule, provides for the monetary allowance of employees based on the features of state regulation of this sphere and varies according to the source of financing and principles for determining the amount of the remuneration and compensatory payments, payments in connection with moving to a new place of service and quality of life of the state of a temporary service location.

\section{References:}

Gordienko, V. V. (2007). Mezhdunarodnoie politseiskoie sotrudnichestvo v usloviiakh globalizatsii kriminalnykh protsessov [International police cooperation in the context of the globalization of criminal processes]. Trudy Akademii upravleniia MVD Rossii [Works of the Academy of Management of the Russian Ministry of Internal Affairs], 2, 8-12. (in Russian)

Gubanov, A.V. (2000). Politsiia zarubezhnykh stran. Organizatsionno-pravovyie osnovy, strategiia i taktika deiatelnosti. [Police of foreign countries. Organizational and legal bases, strategy and tactics of activity]. Moscow: MAEP, 288 p. (in Russian)

Zimin, V., Zubov, I. (1993). Mezhdunarodnoie sotrudnichestvo v oblasti borby s prestupnostiu i okhrany obshchestvennogo poriadka [International cooperation in the field of combating crime and protecting public order]. Moscow, $155 \mathrm{p}$. (in Russian)

Fronteks - Yevropeiskoie agentstvo po upravleniiu operativnym sotrudnichestvom na vneshnikh granitsakh gosudarstv-chlenov Yevropeiskogo Soiuza [Frontex, the European Agency for the Management of Operational Cooperation on the External Borders of the Member States of the European Union]. Retrieved from http://soderkoping.org.ua/page19813.html. (in Russian)

Yak staty politseyskym atashe chy ofitserom zviazku [How to become a police officer or a communications officer]. Retrieved from http://innerbody.com/wordpress3/careers-in-criminal-justice/how-to-become-an-attache-orpolice-liaison-officer.html. (in Ukrainian)

General politsii predpochel Vashingtonu Iudeiu i Samariiu [The general of the police preferred Washington to Judea and Samaria]. Retrieved from http://cursorinfo.co.il/news/novosti. 2007.5 june. (in Russian)

Yak staty politseiskym atashe chy ofitserom zviazku [How to become a police officer or a communications officer]. Retrieved from http://elconfidencial. 2010.29 june. (in Ukrainian)

Mizhnarodna myrotvorcha diialnist MVS Ukrainy. Perspektyvy rozvytku na 2015 rik [International Peacekeeping Activities of the Ministry of Internal Affairs of Ukraine. Development prospects for 2015]. Retrieved from http://www.naiau.kiev.ua/smc/images/stories/mmdu_2013.pdf. (in Ukrainian)

Pro rishennia Rady natsionalnoi bezpeky i oborony Ukrainy vid 24 kvitnia 2009 roku 'Pro Stratehiiu mizhnarodnoi myrotvorchoi diialnosti Ukrainy’: Ukaz Prezydenta Ukrainy vid 15.06.2009 №435/2009 [On the decision of the National Security and Defense Council of Ukraine dated April 24, 2009 'On the Strategy of International Peacekeeping Activity of Ukraine’: Decree of the President of Ukraine. (June 15,2009). No. 435/2009. (in Ukrainian) Retrieved from http://zakon5.rada.gov.ua/laws/show/435/2009.

Pro uchast Ukrainy v mizhnarodnykh operatsiiakh z pidtrymannia myru i bezpeky: Zakon Ukrainy vid 23.04.1999 r. [On Participation in International Peacekeeping and Security Operations: The Law of Ukraine]. (April 23, 1999). Retrieved from http://zakon3.rada.gov.ua/laws/show/613-14. (in Ukrainian)

Pro zatverdzhennia Poriadku materialno-tekhnichnoho i finansovoho zabezpechennia natsionalnoho kontynhentu ta natsionalnoho personalu Ukrainy, yakyi bere uchast u mizhnarodnykh operatsiiakh z pidtrymannia myru i bezpeky: Postanova Kabinetu Ministriv Ukrainy vid 11 lypnia 2002 r. № 963 [On Approval of the Procedure for Logistical and Financial Support of the National Contingent and National Personnel of Ukraine Participating 
in International Peacekeeping Operations: Resolution of the Cabinet of Ministers of Ukraine]. (July 11, 2002). No. 963. Retrieved from http://zakon2.rada.gov.ua/laws/show/963-2002-\%D0\%BF. (in Ukrainian)

Pro zatverdzhennia Instruktsii shchodo orhanizatsii prokhodzhennia sluzhby pratsivnykamy orhaniv vnutrishnikh sprav, viiskovosluzhbovtsiamy vnutrishnikh viisk MVS Ukrainy, yaki napravleni dlia uchasti v mizhnarodnykh operatsiiakh z pidtrymannia myru i bezpeky: Nakaz MVS Ukrainy vid 07.12.2003 № 1490 [On approval of the Instruction on the organization of service of the personnel of the internal affairs bodies, servicemen of internal troops of the Ministry of Internal Affairs of Ukraine, which are sent to participate in international peace and security operations: The Order of the Ministry of Internal Affairs of Ukraine]. (December 07, 2003). No. 1490. Retrieved from http://zakon5.rada.gov.ua/laws/show/z0280-04. (in Ukrainian)

Deiaki pytannia finansovoho zabezpechennia viiskovosluzhbovtsiv Natsionalnoi hvardii ta politseiskykh, vkliuchenykh do skladu natsionalnoho personalu dlia uchasti v mizhnarodnykh operatsiiakh z pidtrymannia myru i bezpeky: Postanova Kabinetu Ministriv Ukrainy vid 22 travnia 2013 r. № 358 [Some issues of financial support for National Guard soldiers and police officers included in national personnel for participation in international peace and security operations: Resolution of the Cabinet of Ministers of Ukraine]. (May 22, 2013). No. 358. Retrieved from http://zakon3.rada.gov.ua/laws/show/358-2013-\%D0\%BF. (in Ukrainian) 